\title{
UNIVERSITY DEVELOPMENT IN GREAT BRITAIN
}

$\mathrm{T}$ HE University Grants Committee has always regarded itself fundamentally as a channel of communication between the State and the universities of Great Britain, and before the War this function we pressed mainly in the interpretation to the Goy himent of the policies and financial needs of the duversities. The increasing dependence of the undesities on Government support makes it fually important that these policies and needs should a so be interpreted to the general public. That function is admirably discharged by the present report*, which summarizes conveniently, with diagrams and comparative statistics, the changes that have occurred in what has probably been the most eventful twelve years in the history of most, if not all, of the universities of Great Britain. Although the new terms of reference of the Committee will make it increasingly concerned with the task of assisting the universities to plan their developments on lines that will meet as closely as possible the needs of the community, the new function will never diminish the importance of the old one of interpretation, both to the Government and to the community.

Before discussing post-war developments and problems, which occupy almost three-quarters of the report, the Committee deals briefly, in successive chapters, with the period 1935-39, the war years and with the revival of the universities after the War; and the narrative is illustrated by numerous appendixes which record changes in the membership of the Committee itself since 1936, the membership of the sub-committees constituted to deal with its new functions, university income and expenditure under main heads, capital benefactions and major additions to university buildings for 1946-47 in comparison with 1935-36, total numbers of students for 1938-39 and in the autumn term 1947 and of assisted students. Details are given of the arrangements for the deferment and call-up of university students, the call-up of university staffs for national service and of the war-time location of the University of London, its colleges and schools. Indeed, the report is a well-nigh indispensable reference work on university development in Britain, and the change in format will render its use for such purposes more generally convenient. Publication of the annual statistical volume of Returns from Universities and University Colleges in receipt of Treasury Grant, suspended since 1938-39, is to be resumed with the volume covering the academic year 1947-48.

The three changes recorded in the grant list since the last report in 1936 are the grant by the Privy Council to University College, Nottingham, of a charter of incorporation as a full university, the formal admission of the University Colleges of Leicester and Hull to the grant list, and approval of financial support for the establishment of a new University College at Stoke-on-Trent, subject to the grant of the necessary royal charter and arrangements for effective sponsorship by one or more universities. During the whole period covered by the report, the total income of the universities of

- University Development from 1935 to 1947 . Being the Report of the University Grants Committee. Pp. 106. (London: H.M. Stationery Office, 1948.) 28. net.
Britain was more than doubled, rising from $£ 6,060,995$ in $1935-36$ to $£ 13,043,541$ in $1946-47$, the principal increases being $\mathfrak{£ 4}, 803,000$ from Parlia. mentary grants, $£ 1,052,000$ from students' fees, $£ 342,000$ from endowments and $£ 194,000$ from local authorities. The increase in the Exchequer grant came mainly in 1945, and the proportion of the total income of the universities which is derived from the State has now risen from $34 \cdot 3$ per cent in 1935-36 to $52 \cdot 7$ per cent, and by 1951-52 may well be more than 60 per cent.

Before discussing the implications of this development, the report refers to non-recurrent grants and to the acceptance in principle, by the Chancellor of the Exchequer, of the Committee's estimate that the capital needs of the universities for the quinquennium 1947-52 would amount to some $£ 40,000,000$ for new building and $£ 10,000,000$ for site and equipment, of which by far the greater part would have to be found, if at all, by the Exchequer. At the same time, the Chancellor indicated that in view of unavoidable restrictions on new construction, it was unlikely that more than $£ 20,000,000$ of building work would be possible in the quinquennium, and subsequent deterioration in the building situation makes it very doubtful whether even this estimate can be fulfilled. Nevertheless, capital benefactions received by the universities during the twelve years under review amounted to $£ 14,366,872$, of which $£ 5,996,636$ was for the erection of new buildings or the acquisition of land and properties, $£ 6,798,794$ for endowments and $£ 1,571,442$ for the establishment of fellowships, scholarships and prizes. During the years 1935-36 to $1944-45$, approximately $£ 6,700,000$ was expended by the universities on the erection of new buildings and purchase of properties, chiefly before the War. Total expenditure in $1946-47$ was $£ 12,951,071$ as against $£ 6,141,401$ in $1935-36$.

The quinquennial system of assessing grants was re-introduced in 1947, and by 1951-52 the contribution from the Exchequer to recurrent university purposes will have risen to about $£ 13,000,000$. The new and enlarged conception of the responsibility of the State in the field of university education has caused the Committee to reconsider seriously the principles which should govern the distribution among the universities of the money at its disposal. It considers its function to be not direction, but stimulation, co-ordination and advice ; consequently, although the Committee has earmarked certain grants for special fields of study for reasons of national policy, it regards this device as unsuitable for permanent adoption because it impairs to some extent the universities' freedom of action. This principle of directing public money most freely into the channels in which it seems likely to produce the most fruitful results - a policy of helping those who help themselves - unlike the obvious criteria of need, is one that may favour the senior universities and those moderm universities which have received the largest measure of support. Endowment income in 1946-47 still' remained at $9 \cdot 3$ per cent over Great Britain as a whole but varied widely among the universities, averaging, for example, only $3 \cdot 1$ per cent in the University of Wales as against 10 per cent for those of Scotland. 
The report shows that the University Grants Committee is well aware of the difficulties which may arise in reconciling the claims of achievement with those of need, and it cites professional salaries as a pertinent example. The report details the reasons which led the Committee to recognize variations in such salaries as a permanent feature of university finance in Britain. The Committee finally decided to compromise on a plan which reduced the existing inequalities and recognized for all institutions a standard rate of professional salary, and assessed for each institution a sum which in the Committee's view might properly be expended in raising the salaries of some professors above the standard rate. While the factors to be taken into account in determining this assessment are indicated, the Committee did not seek to determine or to suggest the salary to be paid to a particular professor, and the arrangement is believed to have been accepted by the universities generally as a reasonable settlement.

That example itself indicates something of the character of the new and intricate relationship between the State and the universities which it is a main purpose of the report to illustrate. Moreover, the Committee regards as one of its most important functions that of devising appropriate means of reconciling the central planning of university developments with the maintenance of the essential academic freedoms. The need for some form of central planning is well recognized by the universities themselves, and the Committee believes that such planning is not irreconcilable with academic autonomy. It believes that the duty of ensuring that the large grants from the Exchequer are expended in the way best cal. culated to promote the public welfare can be discharged by the Committee in a relationship between the State and the universities which may properly be conceived as a form of partnership. Indeed, it suggests that the most serious threats to academic autonomy in Great Britain come rather from other external sources, such as benefactions accompanied by restrictive conditions, or from factors which in devious ways diminish the vigour of academic life.

The full extent of university dependence to-day on Government support is revealed not only in the financial sections of the report just outlined. It is further shown in the section of the report which deals with the number of students. After the fall in numbers during the War from 50,000 to 35,500 in $1943-44$, largely in the faculty of arts, where the number of men students fell from nearly 15,000 to about 3,500 , by October 1947 numbers had risen again to 77,000 , and estimates received from the universities by the Committee indicate that by the end of ten years they expect to be able to deal with 88,000 students, or only 2,000 short of the total figure required to meet the recommendations of the Barlow Committee on Scientific Man-power. Expansion has been greater than expected in the Universities of Oxford and Cambridge and in many of the London colleges, but has been mainly in the provincial universities. Pre-war numbers in science and technology have been approximately doubled, but numbers in the faculties of arts have only risen by 50 per cent, and the Committee considers that it is unlikely that additional students in arts will be forthcoming to bring the number up to 10,000 . For some years to come the proportion of students engaged in scientific and technological studies is likely to be higher than it was before the War.
The Committee suggests that this ratio should be kept in mind; but it is more concerned with the question of quality, both of students and of academic standards. Little direct evidence is yet available of the capacity of the schools to provide a largely increased supply of freshmen of the quality necessary for a university career, and the report emphasizes that more than a third of the students at present in the universities are receiving grants under the Further Education and Training Scheme. While this scheme is temporary, the percentage of full-time students receiving assistance in some form or other from public funds had risen in $1946-47$ to 67.9 as compared with $41 \cdot 1$ in $1935-36$, and the University Grants Committee believes that if the present number of students in the universities is to be maintained, still more if it is to be exceeded, subsidies on an unprecedented scale will be needed. The report briefly reviews the new problem of selection which these conditions present, starting with the assumption that the universities must not be deprived of an effective choice of their own entrants; its observa. tions should be carefully noted in considering the recommendations of the Working Party on University Awards which have since been published.

Next, however, the report considers the bearing of the quality of the life and education which the universities are able to provide and the maintenance of university standards. The effect of the war years on those standards is reviewed in an early chapter; while there were certain imponderable gains, the balance was heavily on the debit side. Now the rapid increase in the number of students has imposed heavy strains on staff and students alike, which in some respects have involved serious deterioration in the standards of university life. The Committee is convinced that unless additional accommodation can be speedily provided, the present student numbers cannot be maintained without grave risk of impairing, not only academic standards which can be measured directly by examination results, but also those imponderable elements which form so valuable a part of university life. To quote the report :

"Unless there are considerable additions to accommodation, some universities will not be able to increase their staffs further. Moreover, a number of universities find themselves unable to make the fullest use of their existing staff owing to lack of accommodation for discussion groups and individual tuition. In some universities there is no room in Union or Library for a large proportion of the students; the present shortage of books adds further to the pressure on the libraries. At many universities there are, every day, long queues waiting for places in refectories which, even though enlarged considerably since the war, are quite inadequate for present numbers. A leisured university life with adequate opportunities for regular contacts between staff and students is rarely possible."

Elsewhere in the report the Committee states that there are no universities in Britain in which the provision of large new teaching blocks is not a pressing necessity, and that both teaching and research are seriously hampered by lack of space. Nevertheless, while stressing the vital importance of sufficient private rooms for staff and of taking a broad and imaginative view of the future in planning new libraries or extensions of the libraries, the Committee endorses the view that the further provision of halls of residence should be a primary object of university policy during the next decade, in spite 
of the difficulties of implementing such a policy at present. In many universities the greatest contribution which can be made to student life at this time is the increased provision of central amenities.

Apart from the physical aspects of university expansion and their bearing on the maintenance of university standards, the University Grants Committee is seriously concerned with the staff conditions. Reference has already been made to over-work and lack of leisure; and the point is reiterated in respect of the research worker, whose most elementary need, coming before even that of suitable equipment for research, is that of sufficient leisure from the pressure of other duties. In regard to research equipment, the Committee incidentally again refers to the importance of library expansion, and looks for some improvement in the facilities for the publication of learned works. One of the principal and most difficult problems confronting the universities is that of recruiting academic staff in sufficient numbers for the discharge of their wider responsibilities. Apart from the increase in the student population, in the spring of 1944 only 68 per cent of the holders of full-time teaching posts on normal establishments remained, 78 per cent of senior administrative and 57 per cent of library staffs. Altogether, some 1,380 members were absent in the Forces or on some form of national service. Furthermore, there is now a call for an increase in the ratio of staff to students, partly to permit students to receive much more individual tuition and partly to free more time for research. With the demand for specialized teachers and research workers arising out of the introduction of new subjects, the Committee estimates that the numbers of full-time staff should be increased during the decennium from the pre-war figure of 4,000 to not less than 10,000. By 1946-47 the number had risen to more than 5,500; but the maximum to be expected by the end of the quinquennium is estimated at 8,000 . Questions of salary are discussed in some detail, and the report urges that all universities should review their administrative arrangements with the object of relieving their professors and heads of departments of any duties that do not necessarily demand their personal attention, and also that means should be found of enabling a larger proportion of lecturers to participate more directly in the administrative business of the university.

The report deals very briefly with such general academic problems as the place of research, curricula and teaching methods; but a section discusses a number of specific problems, mostly arising out of Government reports such as those of the Goodenough Committee, the Loveday Committee on Higher Agricultural Education, the Scarborough Committee and the Clapham Committee. The University Grants Committee has itself appointed a separate sub. committee to deal with technology, which will consider the recommendations of the Percy Report; but the work of this Committee falls outside the period of the present report. Finally, the extra-mural work of the universities is reviewed. The majority of the Committee believes that the universities are making and should continue increasingly to make a unique and indispensable contribution to adult education, but that their special function is to foster and intensify study by all means in their power, and to maintain a high standard of qualitative achievement among those engaged in it. The dissipation of resources should be avoided by wise discrimination.

\section{PROBLEMS OF ORGANIC GROWTH}

\author{
By PROF. LUDWIG von BERTALANFFY \\ Zoologisches Institut, University of Vienna, and \\ Middlesex Hospital Medical School, London
}

$\mathrm{O}^{\mathrm{n}}$

RGANIC growth is, without doubt, one of the basic biological phenomena. Physiology presents a wide realm of experiences concerning factors influencing growth; however, the phenomenon of growth itself remains, as yet, unexplained. Many growth formulæ have been proposed, but none has been generally accepted. Recent investigations, however, seem to provide a consistent theory leading to an explanation of growth in its general ccurse as well as in its specific peculiaritios, to quantitative laws allowing calculation and prediction, and towards a unification of the great physiological realms of metabolism, growth and form development ${ }^{1}$.

Animal growth may be considered a result of the counteraction of synthesis and destruction : anabolism and catabolism of the building materials of the body. There is growth so long as building up prevails over breaking down; the organism becomes stationary if and when both processes are equal. This may be expressed in a general formula which contains no hypothetical elements :

$$
\frac{d y}{d t}=\eta y^{n}-x y^{m}
$$

In words : the change in body weight $y$ is given by the difference between synthesis and destruction of building materials; according to general physio. logical experience, these processes will be proportional to some powers, $n, m$, respectively, of the body weight: $\eta$ and $x$ are constants of anabolism and catabolism.

To make use of this consideration, the processes involved must be defined. Catabolism is represented by the continuous loss of building material, and corresponds, in the higher animal, to what is called Abnützungsquote, or quota of wearing out (Rubner). Physiological experience shows that it is, to a good approximation, proportional to body-weight, so that the exponent $m$ can be made equal to 1 .

With respect to anabolism, a number of different cases can be distinguished. A survey of the types known hitherto is given in the accompanying table.

In micro-organisms ${ }^{2}$, the character of the growth curves depends simply on the geometrical shape. In the case of spherical forms (yeast, micrococci) where the ratio of surface to volume decreases with in. creasing size, we find a decrease of growth-rates; on the other hand, rod-shaped forms (bacteria) which grow almost exclusively in length and where, therefore, the surface-volume ratio remains almost constant, show simple exponential growth. The fact that the surface where the intake of material takes place is a regulating factor of growth also in lower animals was demonstrated quantitatively in plan. arians by measurements of the intestinal tract ${ }^{3}$. The most interesting case is, however, growth in multicellular animals.

One of the classical problems of physiology is the dependence of basal metabolism upon body-size. 